\title{
Rancang Bangun Pengaturan Intensitas Sinar Uv (Ultraviolet) Dengan Mikrokontroler PIC Untuk Tanaman
}

\author{
Trisatya Bambang Yulianyo ${ }^{1}$, Arif Johar Taufiq ${ }^{2}$, Aman Suyadi ${ }^{3}$ \\ Program Studi S1 Teknik Elektro, Universitas Muhammadiyah Purwokerto \\ Fakultas Teknik dan Sains, Universitas Muhammadiyah Purwokerto
}

\section{Informasi Makalah}

Dikirim, 2 Mei 2019

Direvisi, 1 Juli 2019

Diterima,

\section{Kata Kunci: \\ Ultraviolet \\ PWM}

RTC

ML8511

\section{INTISARI}

Ultraviolet adalah radiasi elektromagnetis terhadap panjang gelombang yang lebih pendek dari daerah dengan sinar tampak, namun lebih panjang dari sinar-X yang kecil. Radiasi ultraviolet dapat digunakan untuk desinfeksi bakteri pada ruangan dan juga pada tanaman, tetapi radiasi ultraviolet itu juga dapat berdampak negatif bagi makhluk hidup. Radiasi yang ditimbulkan matahari itu terkadang tidak konstan, karena tidak selamanya matahari selalu menyinari bumi, ada kalanya matahari tertutup oleh awan bisa sebentar atau bisa saja lama. Oleh karena itu pada percobaan ini akan melakukan pengaturan sinar ultraviolet menggunakan lampu UV sebagai sumber utama sinar ultraviolet. Pada dasarnya nilai intensitas cahaya lampu berbanding lurus dengan nilai radiasi sinar ultraviolet. Untuk mengatur nilai intensitas lampu ini dapat dilakukan dengan mengatur nilai PWM dari lampu tersebut dengan mengubah tegangan outputnya. Dari hasil percobaan yang dilakukan, mendapatkan nilai PWM yang sebanding dengan nilai radiasi yang sudah dirata - rata pada matahari. tetapi masih memiliki selisih antara nilai radiasi dari lampu UV dengan nilai radiasi dari matahari. Nilai radiasi ini dapat berubah setiap jam nya sesuai data indeksnya. Untuk mengubah nilai setiap jamnya dapat menggunakan Real Time Clock atau RTC. Data indeks ini diambil dari pengukuran nilai radiasi yang diambil pada matahari selama 20 hari setiap jamnya dan nilai tersebut dirata - ratakan. Hasil pengujian pada tanaman didapatkan pengaruh dari lampu ultraviolet terhadap pertumbuhan dan perkembangan tanaman tropis. Tanaman menjadi layu karena suhu tinggi yang dihasilkan lampu UV tersebut. Adapun juga percobaan untuk monitoring nilai radiasi ini menggunakan sensor ML8511. Akan tetapi pada sensor ini lebih akurat bila digunakan di outdoor atau untuk pengambilan nilai radiasi pada matahari. Karena sensor harus di desain sedemikian mungkin agar cahaya dapat focus masuk ke sensor. Dari data sensor ini mendapatkan nilai error yang besar pada saat pengukuran di lampu dan mendapatkan error yang kecil pada pengukuran dimatahari.

\begin{abstract}
Ultraviolet is electromagnetic radiation to wavelengths shorter than areas with visible light, but longer than small X-rays. Ultraviolet radiation can be used to disinfect bacteria in the room and also in plants, but ultraviolet radiation can also have a negative impact on living things. Radiation caused by the sun is sometimes not constant, because not always the sun always shines on the earth, there are times when the sun is covered by clouds for a while or can be long. Therefore in this experiment the ultraviolet light will be used using UV light as the main source of ultraviolet light. Basically the value of the light intensity of the light is directly proportional to the value of ultraviolet light radiation. To adjust the value of the intensity of this lamp can be done by adjusting the PWM value of the lamp by changing the output voltage. From the results of experiments carried out, get a PWM value that is proportional to the radiation value that has been averaged on the sun. but it still has a difference between the radiation
\end{abstract}


value of a UV lamp and the radiation value of the sun. This radiation value can change every hour according to the index data. To change the value every hour you can use Real Time Clock or RTC. This index data is taken from measurements of radiation values taken on the sun for

20 days each hour and the values are averaged. The results of testing on plants obtained the effect of ultraviolet light on the growth and development of tropical plants. The plant withers because of the high temperature produced by the UV lamp. The trial for monitoring the value of this radiation using the ML8511 sensor. However, this sensor is more accurate when used in outdoor or for taking radiation values to the sun. Because the sensor must be designed so that light can focus into the sensor. From this sensor data get a large error value at the time of measurement in the lamp and get a small error in the measurement in the sun.damage occurs so that the continuity of service is maintained.

\section{Korespondensi Penulis:}

Trisatya Bambang Yulianyo

Program Studi S1 Teknik Elektro

Universitas Muhammadiyah Purwokerto

Jl. Raya Dukuh Waluh Purwokerto, 53182

Email: trisatya25@gmail.com

\section{PENDAHULUAN}

Pertumbuhan dan perkembangan tumbuhan baik pada media tanah ataupun hidroponik. Sangat dipengaruhi beberapa hal salah satunya yaitu disebabkan oleh bakteri- bakteri perusak tanaman. Dengan menghilangkan bakteri pada tanaman tersebut atau desinfeksi maka pertumbuhan dan perkembangan pada tanaman tidak terganggu. Desinfeksi ini merupakan salah satu upaya untuk menghilangkan atau membunuh bakteri patogen yang terdapat dalam air maupun tanah. Klor $(\mathrm{Cl} 2)$ merupakan desinfeksi yang paling umum digunakan. Namun klor menghasilkan suatu "disinfection by - products (DBP's)" di air, misalnya Trihalomethanes yang memiliki efek karsinogenik, mutagenik dan mampu menyebabkan kecacatan lahir. Oleh karena itu perlu dipikirkan metoda desinfeksi lain yang tidak berbahaya bagi manusia.

Sinar ultraviolet mempunyai kemampuan dalam menonaktifkan bakteri, virus dan protozoa tanpa mempengaruhi komposisi kimia air. Menurut Okik Hendriyanto Cahyonugroho, absorpsi terhadap radiasi ultraviolet oleh protein, RNA dan DNA dapat menyebabkan kematian dan mutasi sel. Oleh karena itu, sinar ultraviolet dapat digunakan sebagai disinfektan. Sterilisasi menggunakan sinar ultraviolet biasanya digunakan untuk sterilisasi ruangan. Radiasi sinar ultra violet yang dapat membunuh bakteri adalah dengan panjang gelombang antara 220-290 nm dan radiasi yang paling efektif adalah 253,7 nm (Hollaender, 1995). Radiasi adalah proses penyinaran dengan menggunakan bahan mutagen. Akan tetapi, sinar ultraviolet yang berlebihan dapat merusak dan menghambat pertumbuhan tanaman (Lingga, 2005 as cited in Reni Restiani at al., 2015). Radiasi sinar ultraviolet memiliki energi lebih rendah dibandingkan dengan radiasi sinar $\mathrm{x}$, tetapi radiasi ultraviolet juga bisa menyebabkan rusaknya kromosom, karena terjadinya penyerapan energi gelombang panjang oleh bahan dasar asam nukleat, yaitu purin dan pirimidin (Strickberger, 1985 as cited in Zahrotul Firdaus).

Berdasarkan latar belakang tersebut akan dirancang sebuah alat untuk mengatur nilai indeks sinar ultraviolet menggunakan lampu uv, agar nilai indeks sinar ultraviolet terrsebut konstan atau sama setiap harinya, agar baik digunakan untuk tanaman dan tidak merusak tanaman tersebut. diutamakan untuk tanaman indoor karena pada tanaman indoor jarang sekali terkana sinar matahari secara langsung. data indeks sinar ultraviolet ini didapatkan dari pengukuran nilai indeks sinar ultraviolet menggunakan UV Light

Halaman Web JRRE : http://jurnalnasional.ump.ac.id/index.php/JRRE 
Meter selama 7 hari dan diambil data setiap jamnya dari jam 7 pagi hingga jam 5 sore dan diambil nilai rata-rata selama 7 hari tersebut. Yang nantinya data ini digunakan sebagai nilai standardnya. Alat ini bekerja dari jam 7 pagi hingga jam 5 sore dimana indeks ultravioletnya menyesuaikan data standard yang berbeda setiap jamnya. Jadi setiap jamnya nilai indeks ultraviolet ini akan berubah-ubah sesuai dengan nilai indeks standard yang digunakan. Untuk mengatur nilai indeks ultraviolet pada lampu uv ini dengan cara mengatur intensitas cahaya yang dikeluarkan pada lampu uv. Intensitas cahaya yang dihasilkan lampu uv ini akan mempengaruhi nilai dari indeks sinar uv tersebut.

\section{METODE PENELITIAN}

\subsection{Pengambilan Data Indeks dan Intensitas UV}

Pengambilan data indeks ini adalah pengambilan nilai radiasi sinar UV pada matahari dengan menggunakan UV meter. Pengambilan data ini dilakukan dilapangan dan dilakukan setiap jam nya dari pukul 7.00 sampai dengan pukul 16.00 selama 20 hari. Hasil dari data ini dirata - ratakan dan dijadikan data indeks atau data utama pada penelitian

\subsection{Pengambilan Hardware}

Perancangan hardware pertama yaitu menggunakan PIC 16F877A untuk mengatur nilai PWM menggunakan potensio. Komponen yang digunakan yaitu PIC 16F877A, potensiometer, capacitor 22pF, clock 20MHz, resistor 10kOhm, dan LCD. Untuk mengendalikan lampu digunakan rangkaian driver AC. Pada rangkaian driver AC ini komponen yang digunakan yaitu dioda bridge kapasitas 15A, capacitor $10 \mathrm{uF}$ dan $100 \mathrm{uF}$ dengan kapasitas 400V, diode zener IN4007 dan IN4744A, transistor BC547, mosfet IRFP460 dengan kapasitas 16A tegangan drain source $400 \mathrm{~V}$ dan tegangan gate $30 \mathrm{~V}$, resistor $100 \mathrm{kOhm} 1 \mathrm{~W}$, dan optocoupler 4n35. Setelah pengambilan data menggunakan potensio, langkah selanjutnya membuat alat agar bekerja automatis dengan memberikan timer pada rangkaian. Komponen yang digunakan masih sama hanya saja potensiometer digantikan dengan RTC DS1307.

\subsection{Perancangan Software}

Perancangan hardware tidak akan berfungsi jika software tidak dirancang, dimana perancangan software berfungsi untuk mengendalikan atau memerintah suatu sistem. Komponen utama dan mikrokontroler PIC 16F874A adalah sebagai input, output, serta pengendali yang membutuhkan suatu program agar komponen tersebut dapat berjalan. Pembuatan kode program pada penelitian ini menggunakan IDE MPLAB sebagai software untuk pemrogramannya. IDE MPLAB merupakan software yang di keluarkan atau di produksi oleh perusahan Microchip yang juga memproduksi mikrokontroler PIC dimana software tersebut sudah terintegrasi dengan mikrokontroler PIC, IDE MPLAB terpisah dengan compiler-nya dimana MPLAB IPE sebagai compiler-nya.

\section{HASIL DAN PEMBAHASAN}

Halaman Web JRRE : http://jurnalnasional.ump.ac.id/index.php/JRRE 


\subsection{Pengambilan Data Radiasi Matahari}

Pengukuran radiasi matahari didapatkan hasil seperti pada Gambar 3.1. dimana nilai tertinggi berada pada pukul jam 12.00 dan paling rendah pada pukul 16.00.

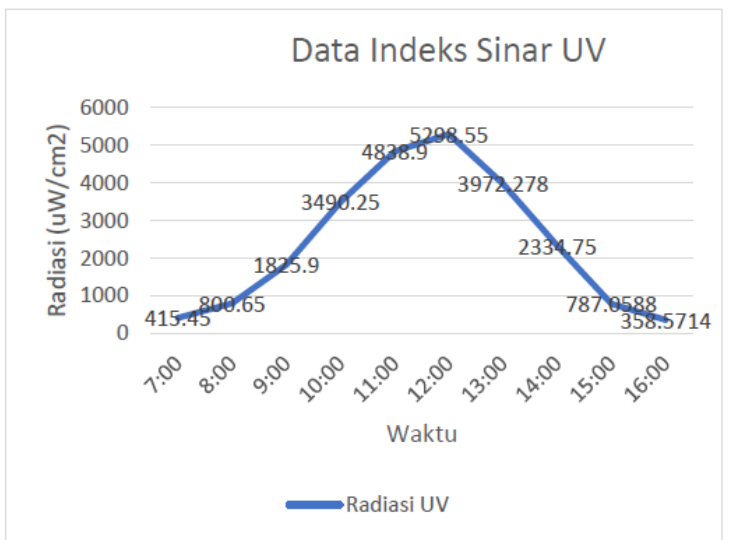

Gambar 3.1. Grafik Pengukuran Radiasi pada Matahari

\subsection{Pengaturan Nilai PWM Terhadap Nilai Intensitas UV}

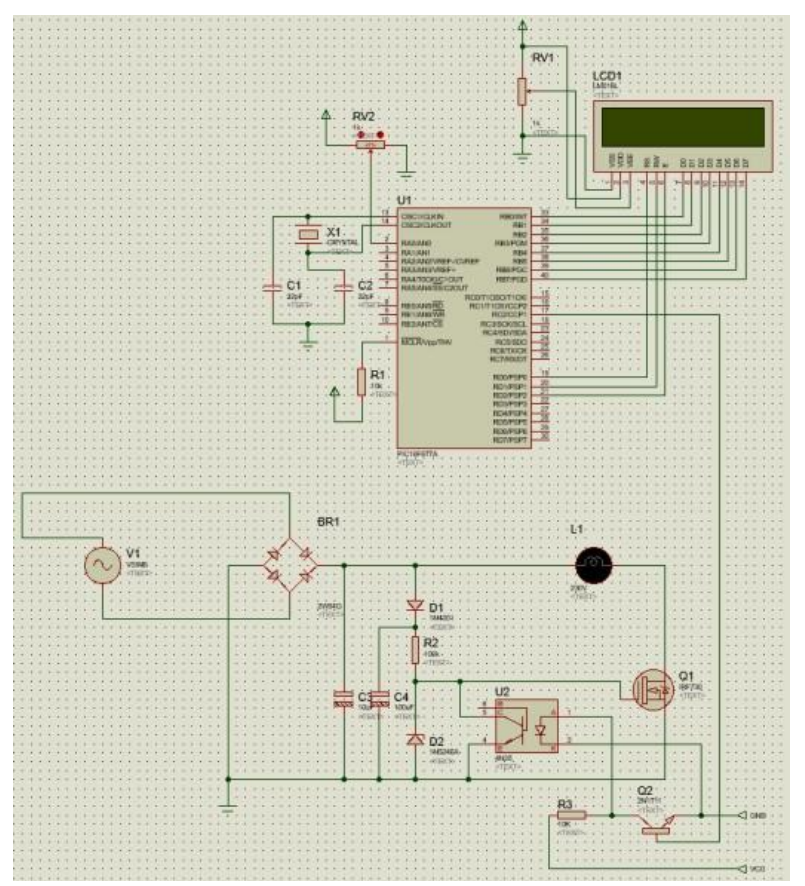

Gambar 3.2. Rangkaian pengaturan PWM Lampu UV dengan Potensio

Rangkaian ini dapat menampung beban lampu sebesar 1000W. akan tetapi tegangan beban akan turun mengikuti beban yang diberikan. Hal ini dikarenakan tegangan yang dihasilkan bukan tegangan AC 
murni, karena terdapat diode bridge didalamnya. Jadi tegangan campuran antara DC dan AC. Hasil sinyal PWM keluaran dari mikro ini pada gambar 3.3. dan 3.4.

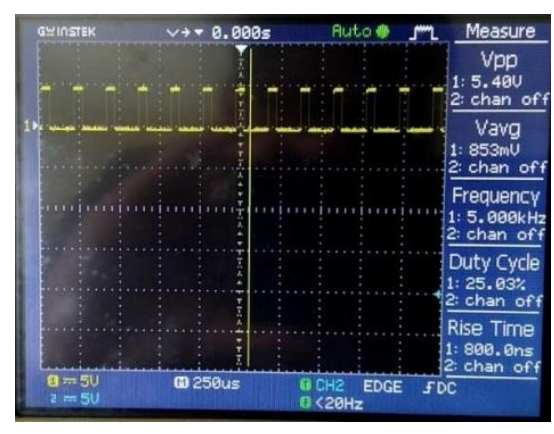

Gambar 3.3. PWM posisi $25 \%$

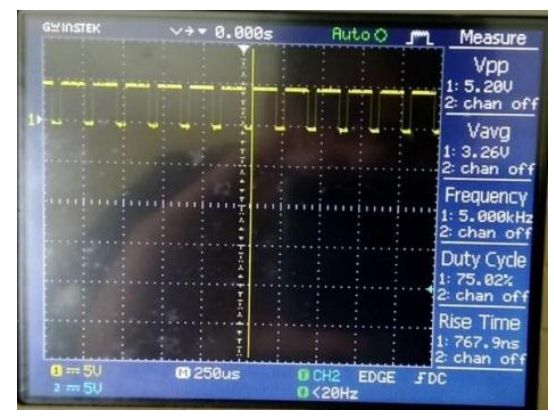

Gambar 3.4. PWM posisi $75 \%$

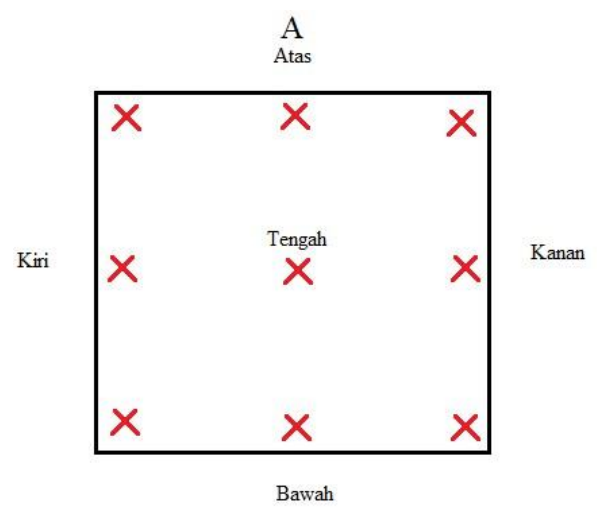

Gambar 3.5. Posisi Pengambilan Data Radiasi pada Lampu

Pengukuran ini menggunakan kotak dengan ukuran 20x20 cm, dengan tinggi 1m, dan rak disetiap $10 \mathrm{~cm}$. rak ini digunakan untuk tempat lampu UV ini diletakkan agar menggantung kebawah. Huruf 
A pada gambar itu digunakan sebagai tempat pengukuran atau tempat dimana UV meter itu diletakkan. pada tempat pengukuran tersebut terdapat tanda silang merah di beberapa titik. tanda silang merah tersebut adalah posisi UV meter saat melakukan pengukuran untuk mendapatkan nilai radiasi lampu UV. Penggunaan kotak ini bertujuan agar pada saat melakukan pengukuran, UV meter dan lampu tidak berubah posisi. Karena bila terjadi perubahan posisi itu akan mempengaruhi nilai radiasi dari lampu tersebut. Dan melakukan pengukuran radiasi dibeberapa titik itu bertujuan untuk mengetahui nilai radiasi pada lampu UV yang berada tidak di tengah lampu atau dititik focus lampu, dan juga untuk mengetahui nilai radiasi keseluruhan yang tersebar di kotak tersebut. Dari hasil yang didapat Maksud dari kiri kanan dan atas bawah itu adalah posisi alat ukur saat melakukan pengukuran seperti tanda silang pada gambar 3.5. Hasil yang didapatkan dari pengukuran ini pada tabel 3.1. sampai dengan tabel 3.3.

Tabel 3.1. Pengukuran Radiasi UV di Beberapa Titik (1 Lampu,satuan uW/cm²)

\begin{tabular}{|c|c|c|c|c|c|c|c|c|c|c|c|}
\hline \multirow[t]{2}{*}{$\mathrm{NO}$} & \multirow[t]{2}{*}{ Jarak } & \multirow[t]{2}{*}{ Tengah } & \multicolumn{2}{|c|}{ Kiri } & \multicolumn{3}{|c|}{ Tengah } & \multirow[b]{2}{*}{ Bawah } & \multicolumn{2}{|c|}{ Kanan } & \multirow[t]{2}{*}{ Rata2 } \\
\hline & & & Atas & Bawah & Kanan & Kiri & Atas & & Atas & Bawah & \\
\hline 1 & 10 & 13150 & 157 & 123 & 237 & 291 & 309 & 198 & 133 & 94 & 1632,44 \\
\hline 2 & 20 & 2332 & 340 & 347 & 719 & 782 & 661 & 586 & 382 & 230 & 708,78 \\
\hline 3 & 30 & 912 & 374 & 432 & 899 & 970 & 524 & 476 & 639 & 247 & 608,11 \\
\hline 4 & 40 & 517 & 284 & 472 & 561 & 600 & 423 & 362 & 525 & 238 & 442,44 \\
\hline 5 & 50 & 322 & 207 & 369 & 407 & 365 & 255 & 318 & 381 & 214 & 315,33 \\
\hline 6 & 60 & 245 & 171 & 301 & 300 & 279 & 207 & 235 & 279 & 193 & 245,56 \\
\hline 7 & 70 & 186 & 142 & 232 & 223 & 215 & 171 & 184 & 215 & 167 & 192,78 \\
\hline 8 & 80 & 148 & 122 & 176 & 172 & 171 & 139 & 145 & 172 & 131 & 152,89 \\
\hline \multicolumn{5}{|c|}{$\begin{array}{l}\text { Vin }=200 \mathrm{~V} \mathrm{AC} \\
\text { Vout }=225 \mathrm{~V} \mathrm{DC} \\
\text { Daya }=75 \mathrm{~W}\end{array}$} & \multicolumn{7}{|c|}{ Vin $=$ Tegangan PLN, Vout $=$ Tegangan Beban } \\
\hline
\end{tabular}

Tabel 3.2. Pengukuran Radiasi UV di Beberapa Titik (2 Lampu)

Halaman Web JRRE : http://jurnalnasional.ump.ac.id/index.php/JRRE 


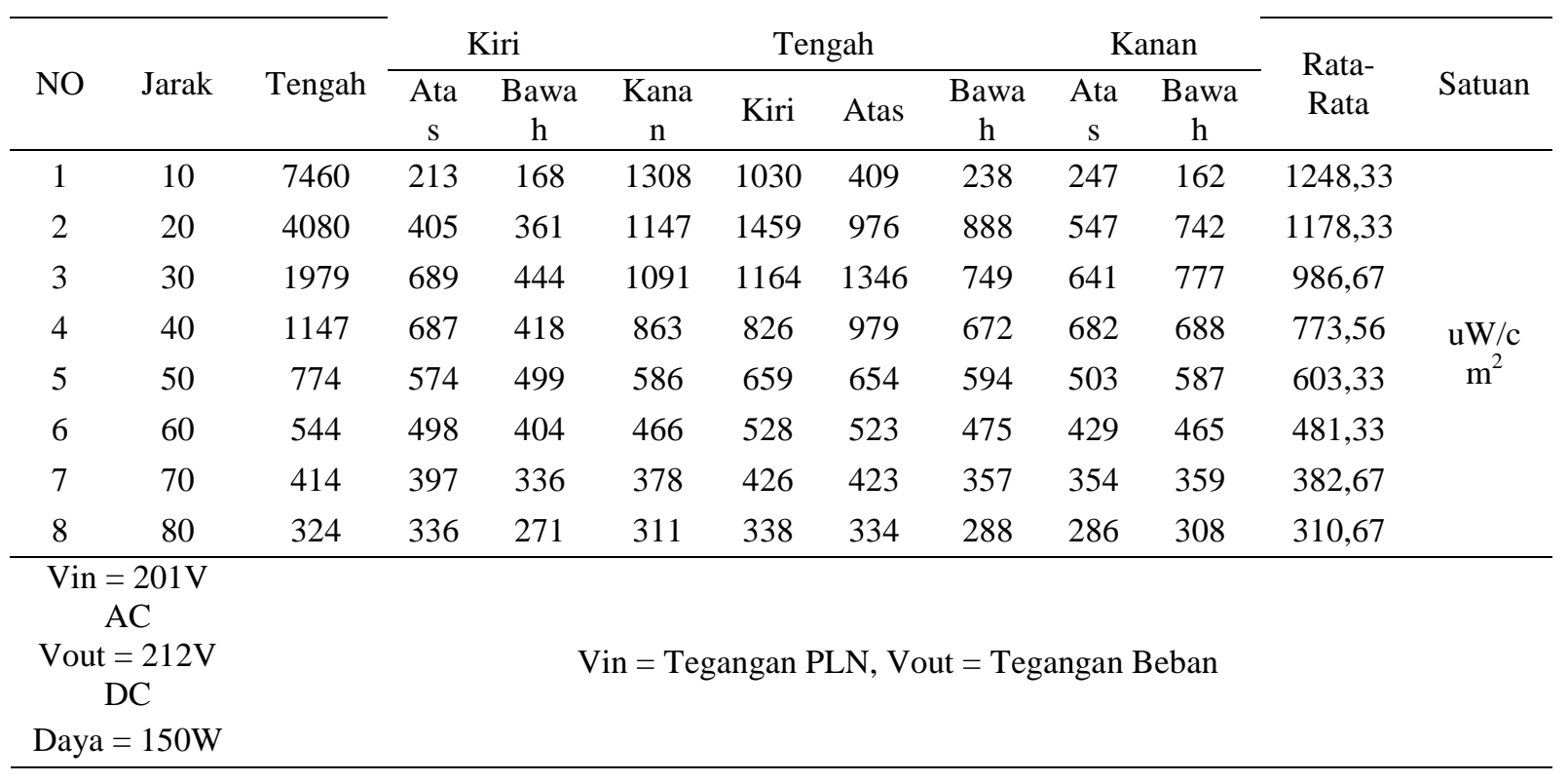

Tabel 3.3. Pengukuran Radiasi UV di Beberapa Titik (4 Lampu)

\begin{tabular}{|c|c|c|c|c|c|c|c|c|c|c|c|c|}
\hline \multirow[b]{2}{*}{ NO } & \multirow[b]{2}{*}{ Jarak } & \multirow[b]{2}{*}{ Tengah } & \multicolumn{2}{|c|}{ Kiri } & \multicolumn{4}{|c|}{ Tengah } & \multicolumn{2}{|c|}{ Kanan } & \multirow{2}{*}{$\begin{array}{l}\text { Rata- } \\
\text { Rata }\end{array}$} & \multirow[b]{2}{*}{ Satuan } \\
\hline & & & Atas & $\begin{array}{c}\text { Bawa } \\
\mathrm{h}\end{array}$ & $\begin{array}{c}\text { Kana } \\
\mathrm{n}\end{array}$ & Kiri & Atas & $\begin{array}{c}\text { Baw } \\
\text { ah }\end{array}$ & Atas & $\begin{array}{c}\text { Baw } \\
\text { ah }\end{array}$ & & \\
\hline 1 & 10 & 3650 & 499 & 328 & 2274 & 2449 & 7590 & 2769 & 387 & 276 & 2246,89 & \\
\hline 2 & 20 & 4940 & 1152 & 1073 & 2311 & 1659 & 2727 & 1865 & 1018 & 703 & 1938,67 & \\
\hline 3 & 30 & 2715 & 1358 & 1121 & 1782 & 1496 & 1836 & 1597 & 1339 & 769 & 1557 & \\
\hline 4 & 40 & 1638 & 1018 & 985 & 1391 & 1251 & 1429 & 1122 & 1253 & 794 & 1209 & $\mathrm{uW} / \mathrm{c}$ \\
\hline 5 & 50 & 1089 & 812 & 882 & 1022 & 935 & 1004 & 887 & 972 & 782 & 931,67 & $\mathrm{~m}^{2}$ \\
\hline 6 & 60 & 815 & 661 & 722 & 755 & 738 & 762 & 665 & 769 & 635 & 724,67 & \\
\hline 7 & 70 & 619 & 537 & 574 & 599 & 590 & 614 & 555 & 605 & 530 & 580,33 & \\
\hline 8 & 80 & 485 & 442 & 464 & 471 & 490 & 487 & 446 & 468 & 415 & 463,11 & \\
\hline $\begin{array}{r}\text { Vout } \\
\text { D } \\
3 \\
\end{array}$ & $\begin{array}{l}=197 \mathrm{~V} \\
\mathrm{C} \\
\mathrm{ya}= \\
0 \mathrm{~W}\end{array}$ & \multicolumn{11}{|c|}{ Vout $=$ Tegangan PLN } \\
\hline
\end{tabular}

Percobaan dilakukan di dalam ruang dimana nilai tegangannya tidak konstan atau berubah - ubah. Dari tabel data hasil pengukuran (tabel 4.2. sampai dengan table 3.7.), lampu yang digunakan adalah lampu UV jenis bulp atau lampu pijar, yang memiliki daya $75 \mathrm{~W}$. lampu ini menghasilkan radiasi UV maksimal sebesar kurang lebih $14.000 \mathrm{uW} / \mathrm{cm}^{2}$ pada pengukuran jarak $10 \mathrm{~cm}$. jarak juga mempengaruhi besar dan kecilnya radiasi pada lampu UV. Disini tegangan pada Driver mosfet juga mengalami penurunan, 
semakin besar daya yang digunakan tegangan output Driver mosfet akan turun, 1 lampu memiliki daya $75 \mathrm{~W}$ dan menghasilkan tegangan 225V DC sedangkan 2 lampu memiliki daya $150 \mathrm{~W}$ dan menghasilkan tegangan 212V DC, begitu juga pengukuran 300W atau 4 lampu tegangan menjadi 190V DC, bisa dikatakan drop tegangan yang terjadi disini adalah 225-212 $=13 \mathrm{~V} \mathrm{DC}$, dan 212-26 = 186V DC, maka kurang lebih tegangan drop beban sebesar 13V DC setiap penambahan beban 1 lampu atau $75 \mathrm{~W}$.

Hal ini bisa dikarenakan mosfet yang digunakan tidak mampu menahan beban yang besar, walaupun spesifikasi mosfet tersebut mampu menerima beban besar. Dan berdasarkan pada pengukuran lampu pada Tabel 3.1. sampai dengan 4.3, 1 lampu nilai tengahnya lebih tinggi dibandingkan 2 lampu atau 4 lampu. Itu dikarenakan pada 1 lampu, lampu akan focus disatu titik ditengah, jadi titik focus lampu berada tepat ditengah automatis cahaya akan lebih terang dibandingkan 2 lampu atau 4 lampu yang tidak focus ditengah. Jadi titik focus suatu lampu atau titik terang maksimal suatu lampu itu mempengaruhi besar kecilnya nilai radiasi. Tetapi bila dibandingkan pengukuran 2 lampu dengan 4 lampu, disini radiasi yang didapat lebih besar 4 lampu, padahal saat pengukuran 2 lampu dan 4 lampu pengukuran tidak pada titik focus. Yang artinya daya suatu lampu mempengaruhi nilai besar kecilnya radiasi. Dimana daya yang besar akan menghasilkan nilai radiasi yang besar disbandingkan daya yang kecil. Disini 2 lampu memiliki daya 150W, sedangkan 4 lampu memiliki daya $300 \mathrm{~W}$.

$X=5298,55 / 912=5,8$

Jadi lampu yang dibutuhkan pada jarak

$30 \mathrm{~cm}$ adalah 6 lampu

$\mathrm{P}=75 \times 6=450 \mathrm{~W}$

berikut:

Karna menggunakan 6 lampu maka didapatkan perhitungan radiasi di setiap jamnya seperti data

Pada pukul 7.00 radiasi pada indeks adalah

415,45, maka

Pukul 7.00 = 415,45 / X = 415,15 / 6

$=69,24 \mathrm{uW} / \mathrm{cm}^{2}$

Dan seterusnya hingga pada pukul 16.00.

Tabel 3.4 Perhitungan Jumlah Lampu dan Nilai PWM dari Data Indeks

Halaman Web JRRE : http://jurnalnasional.ump.ac.id/index.php/JRRE 


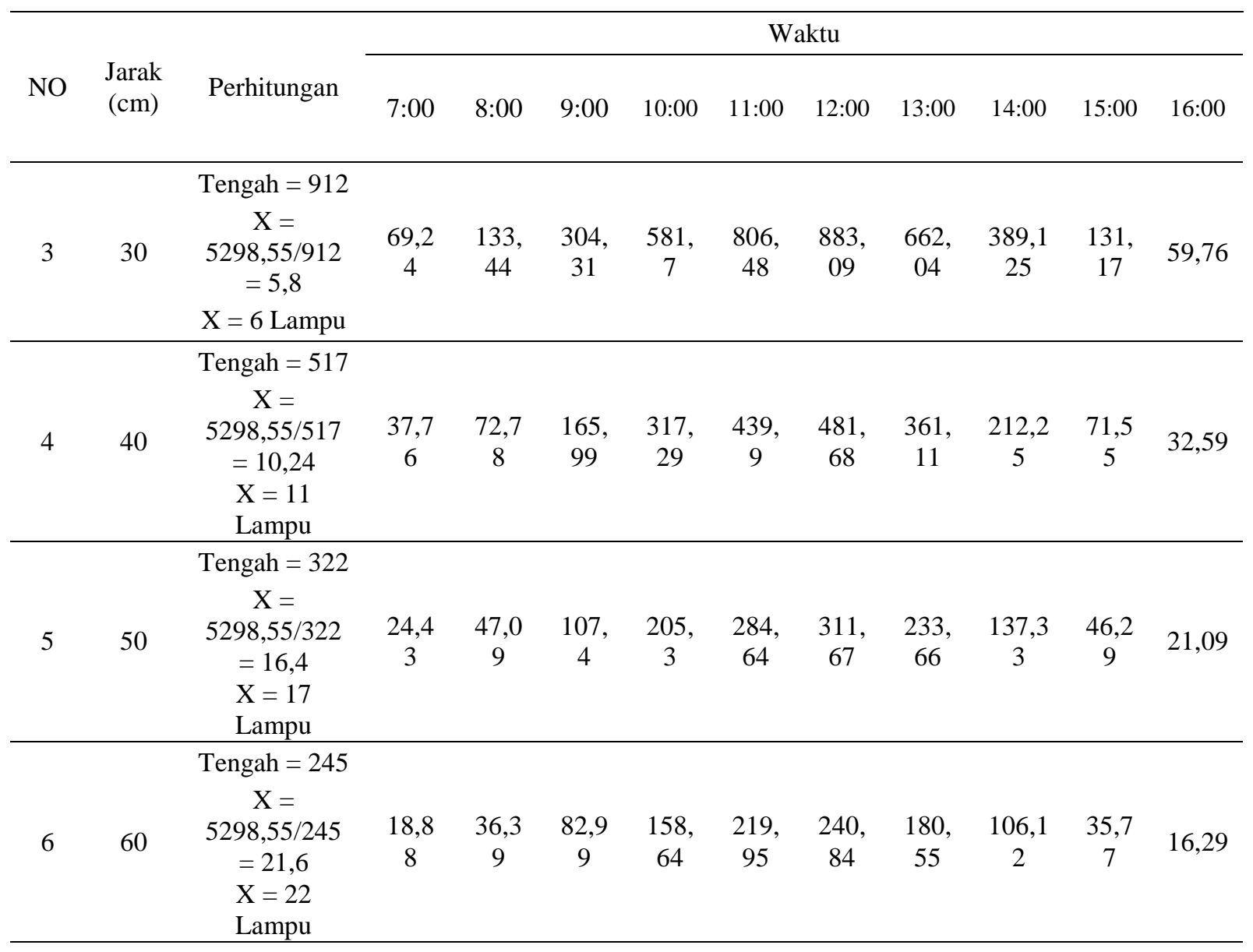

Tabel 3.5. Tabel Pengukuran UV dan PWM

\begin{tabular}{llll}
\hline NO Jarak Pengukura & Waktu \\
\hline
\end{tabular}




\begin{tabular}{|c|c|c|c|c|c|c|c|c|c|}
\hline \multicolumn{2}{|c|}{$(\mathrm{cm})$} & \multirow[t]{2}{*}{$\mathrm{n}$} & \multirow[b]{2}{*}{$7: 00$} & \multirow[b]{2}{*}{$9: 00$} & \multirow[b]{2}{*}{ 11:00 } & \multirow[b]{2}{*}{$13: 00$} & \multirow[b]{2}{*}{$14: 00$} & \multirow[b]{2}{*}{$15: 00$} & \multirow[b]{2}{*}{$16: 00$} \\
\hline & & & & & & & & & \\
\hline \multirow{3}{*}{3} & \multirow{3}{*}{30} & PWM (\%) & $\begin{array}{c}24,9266 \\
9\end{array}$ & $\begin{array}{c}50.0488 \\
8\end{array}$ & $\begin{array}{c}83,0889 \\
5\end{array}$ & 79,7654 & $\begin{array}{c}53,0791 \\
8\end{array}$ & 31,1828 & $\begin{array}{c}24,8289 \\
3\end{array}$ \\
\hline & & $\begin{array}{c}\mathrm{UV} \\
\left(\mathrm{uW} / \mathrm{cm}^{2}\right)\end{array}$ & 69,9 & 308,8 & 822 & 680 & 397 & 138 & 65,1 \\
\hline & & $\begin{array}{l}\text { Tegangan } \\
\text { (V) }\end{array}$ & 37 & 97 & 193 & 179 & 119 & 55 & 36 \\
\hline \multirow{3}{*}{4} & \multirow{3}{*}{40} & PWM (\%) & $\begin{array}{c}24,9266 \\
9\end{array}$ & $\begin{array}{c}46,9208 \\
2\end{array}$ & $\begin{array}{c}83,0889 \\
5\end{array}$ & $\begin{array}{c}75,0733 \\
1\end{array}$ & $\begin{array}{c}50,7331 \\
4\end{array}$ & $\begin{array}{c}30,4985 \\
3\end{array}$ & $\begin{array}{c}24,6334 \\
3\end{array}$ \\
\hline & & $\begin{array}{c}\mathrm{UV} \\
\left(\mathrm{uW} / \mathrm{cm}^{2}\right)\end{array}$ & 33,1 & 187,2 & 458 & 369,3 & 220,9 & 73,2 & 34,3 \\
\hline & & $\begin{array}{c}\text { Tegangan } \\
\text { (V) }\end{array}$ & 37 & 104 & 193 & 169 & 114 & 54 & 35 \\
\hline \multirow{4}{*}{5} & \multirow{4}{*}{50} & PWM (of) & 26,3929 & 43,7927 & 83,0889 & 75,0733 & 50,0488 & 30,4985 & 24,8289 \\
\hline & & PWM (\%) & 6 & 7 & 5 & 1 & 8 & 3 & 3 \\
\hline & & $\begin{array}{c}\mathrm{UV} \\
\left(\mathrm{uW} / \mathrm{cm}^{2}\right)\end{array}$ & 29,3 & 111,9 & 285,6 & 244,2 & 139,6 & 46,9 & 22,4 \\
\hline & & $\begin{array}{c}\text { Tegangan } \\
\text { (V) }\end{array}$ & 40 & 96 & 193 & 169 & 112 & 54 & 35 \\
\hline \multirow{4}{*}{6} & \multirow{4}{*}{60} & PWM $(\%)$ & 26,3929 & 43,7927 & 83,0889 & 76,5395 & 50,3421 & 30,4985 & 24,8289 \\
\hline & & & 6 & 7 & 5 & 9 & 3 & 3 & 3 \\
\hline & & $\begin{array}{c}\mathrm{UV} \\
\left(\mathrm{uW} / \mathrm{cm}^{2}\right)\end{array}$ & 22,8 & 86,3 & 222.4 & 184,9 & 106,6 & 36,7 & 17,3 \\
\hline & & $\begin{array}{c}\text { Tegangan } \\
\text { (V) }\end{array}$ & 41 & 98 & 193 & 174 & 113 & 55 & 36 \\
\hline
\end{tabular}

Setelah melakukan pengukuran radiasi UV seperti pada tabel 3.4, maka langkah selanjutnya pengukuran data PWM sesuai kebutuhan berdasarkan data indeks. Hasil pengukuran PWM ditunjukkan pada tabel 3.5

Tabel 3.6. Tabel Selisih data PWM 


\begin{tabular}{cccc}
\hline NO & $\begin{array}{c}\text { Nilai } \\
\text { Perhitungan }\end{array}$ & $\begin{array}{c}\text { Nilai } \\
\text { Pada } \\
\text { Lampu } \\
\text { UV }\end{array}$ & Selisih \\
\hline 1 & 69,24 & 69,9 & 0,66 \\
2 & 133,44 & 138,4 & 4,96 \\
3 & 304,31 & 308,8 & 4,49 \\
4 & 581,7 & 648 & 66,3 \\
5 & 806,48 & 822 & 15,52 \\
6 & 883,09 & 914 & 30,91 \\
7 & 662,04 & 680 & 17,96 \\
8 & 389,125 & 397 & 7,875 \\
9 & 131,17 & 138 & 6,83 \\
10 & 59,76 & 65,1 & 5,34 \\
\hline
\end{tabular}

Dari data tabel 3.5. didapatkan nilai radiasi sesuai dengan PWM yang diberikan dan memiliki sedikit nilai selisih. Pada jam 7.00 PWM 25\% dan mendapatkan radiasi sebesar $69,9 \mathrm{uW} / \mathrm{cm}^{2}$, dan tegangan yang didapat sebesar 37V DC. Dimana Vin 205V AC dan Vout maksimal beban (PWM 100\%) 230V DC. Dari data tabel 3.6. didapatkan nilai selisih yang didapat dari perhitungan dan pengukuran pada lampu UV ini tidak berbeda jauh atau memiliki nilai selisih yang kecil. Tetapi data ini hanya sebuah perhitungan atau estimasi data agar nilai radiasi yang dibutuhkan bisa mencapai titik maksimalnya atau sesuai data indeks yang diambil dari matahari. tetapi pada kenyataannya setelah diukur menggunakan 6 lampu sesuai dengan perhitungan didapatkan hasil pada tabel 3.7.

Tabel 3.7. Tabel Hasil Pengukuran 6 Lampu pada Jarak 30cm

\begin{tabular}{|c|c|c|c|c|c|c|c|c|c|}
\hline \multirow{2}{*}{$\mathrm{NO}$} & \multirow{2}{*}{$\begin{array}{l}\text { Jarak } \\
(\mathrm{cm})\end{array}$} & \multirow{2}{*}{ Pengukuran } & \multicolumn{7}{|c|}{ Waktu } \\
\hline & & & 7:00 & 9:00 & 11:00 & $13: 00$ & $14: 00$ & $15: 00$ & $16: 00$ \\
\hline \multirow{3}{*}{3} & \multirow{3}{*}{30} & PWM (\%) & 24,92669 & 50,04888 & 83,08895 & 79,7654 & 53,07918 & 31,1828 & 24,82893 \\
\hline & & $\begin{array}{c}\mathrm{UV} \\
\left(\mathrm{uW} / \mathrm{cm}^{2}\right)\end{array}$ & 118 & 818 & 2886 & 2414 & 1154 & 311.4 & 119.1 \\
\hline & & $\begin{array}{c}\text { Tegangan } \\
\text { (V) }\end{array}$ & 27 & 73 & 163 & 144 & 90 & 43 & 26 \\
\hline
\end{tabular}

Data Tabel 3.7 diambil dari pengukuran 6 lampu dimana menggunakan 4 lampu $75 \mathrm{~W}$ dan 2 lampu 100W. dari data tabel 3.7. ini bila berdasarkan teori itu dapat mencapai nilai radiasi yang diinginkan, 
akan tetapi berdasarkan nilai real-nya nilai radiasi yang didapat itu tidak memenuhi nilai radiasi yang diinginkan. Dari pengukuran 6 lampu pada tabel 4.7. bisa mendapatkan nilai radiasi yang diinginkan jika 6 lampu ini dititik focuskan di satu titik dan lakukan pengukuran kembali dititik tersebut itu akan mendapatkan nilai radiasi yang diinginkan. Hanya saja bila melakukan hal tersebut tanaman dipastikan akan mati atau tidak mampu bertahan hidup pada alat ini dikarenakan suhunya yang panas. Jadi nilai perhitungan yang dilakukan ini bisa saja menjadi real bila keenam lampu tersebut difocuskan di satu titik, bila tidak di focuskan di satu titik maka hasil radiasi yang didapat seperti tabel 4.7. Kendala yang sebenarnya dialami itu adalah lampu UV yang digunakan itu tidak ada yang bisa mencapai nilai radiasi sebesar 5298uW/cm2 (nilai maksimal data indeks). Bila ada lampu yang bisa mencapai radiasi tersebut maka akan mudah untuk mendapatkan nilai radiasi yang diinginkan sesuai dengan nilai PWM yang diatur. Jadi jika nilai radiasi matahari di bandingkan dengan nilai lampu UV akan memperoleh hasil seperti pada gambar 3.6.

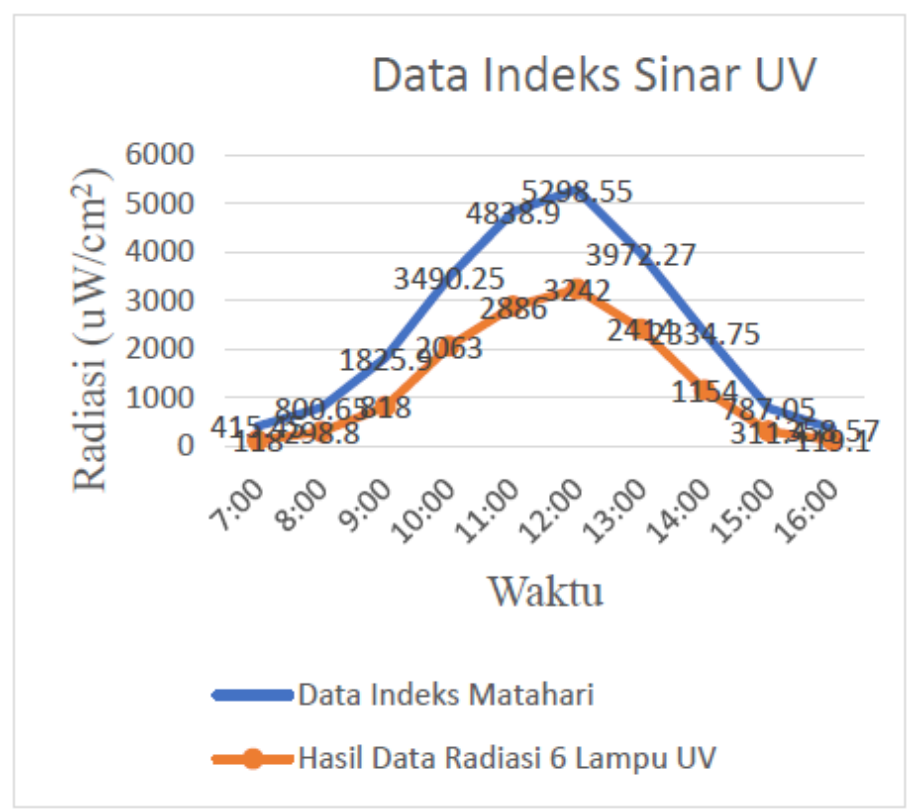

Gambar 3.6. Grafik Perbandingan Nilai Radiasi Lampu dengan Matahari

\subsection{Pengaturan PWM pada RTC yang Sebanding dengan nilai Intensitas UV}

Halaman Web JRRE : http://jurnalnasional.ump.ac.id/index.php/JRRE 


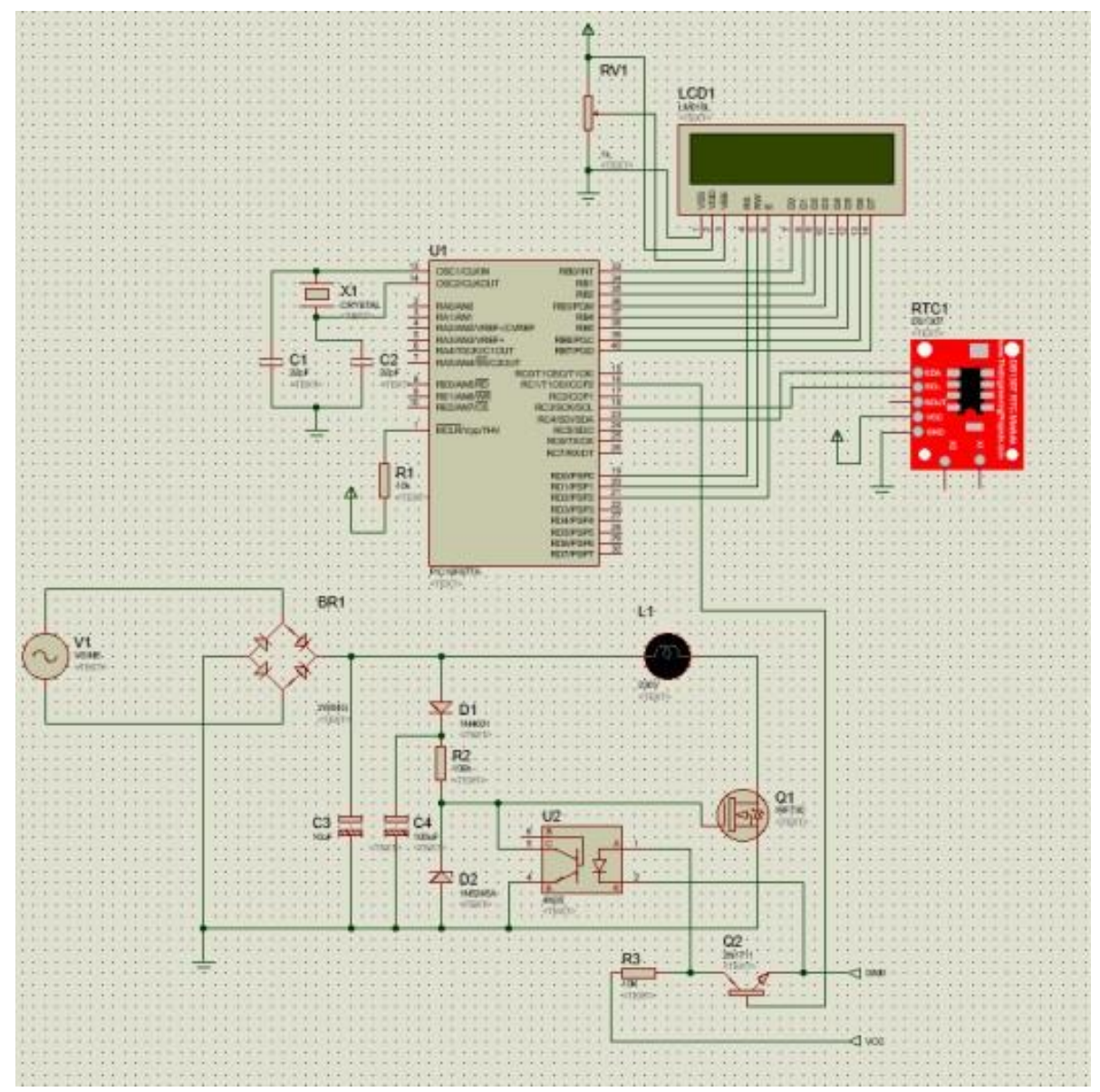

Gambar 3.7 Rangkaian pengaturan PWM Lampu UV dengan RTC

Setelah melakukan pengujian pada tanaman, tanaman tersebut menjadi layu dan kering. Hal ini dikarenakan efek dari suhu tinggi yang dihasilkan oleh lampu UV tersebut. Intensitas sinar UV tidak mempengaruhi tumbuh kembang tanaman, tetapi di pengaruhi oleh radiasi dan suhu yang dihasilkan lampu UV tersebut. Pada percobaan ini menggunakan tanaman yang dapat hidup di iklim sedang. Mungkin akan berbeda hasilnya bila melakukan percobaan pada tanaman yang beriklim panas seperti kaktus. Karena kaktus akan bertahan pada suhu yang panas seperti halnya pada gurun pasir. Percobaan ini dilakukan pada posisi tanaman sedang tumbuh, tidak berawal dari bibit. Tanaman akan tumbuh seperti biasa bila melakukan percobaan saat tanaman masih berupa bibit. Hanya saja pertumbuhan dan perkembangannya pasti akan berbeda bila dibandingkan dengan tanaman yang ditanam normal di perkebunan. Dengan kata lain tanaman dari kecil atau dari bibit ini akan beradaptasi dengan radiasi yang konstan setiap jamnya.

\subsection{Sensor UV ML8511}

Halaman Web JRRE : http://jurnalnasional.ump.ac.id/index.php/JRRE 


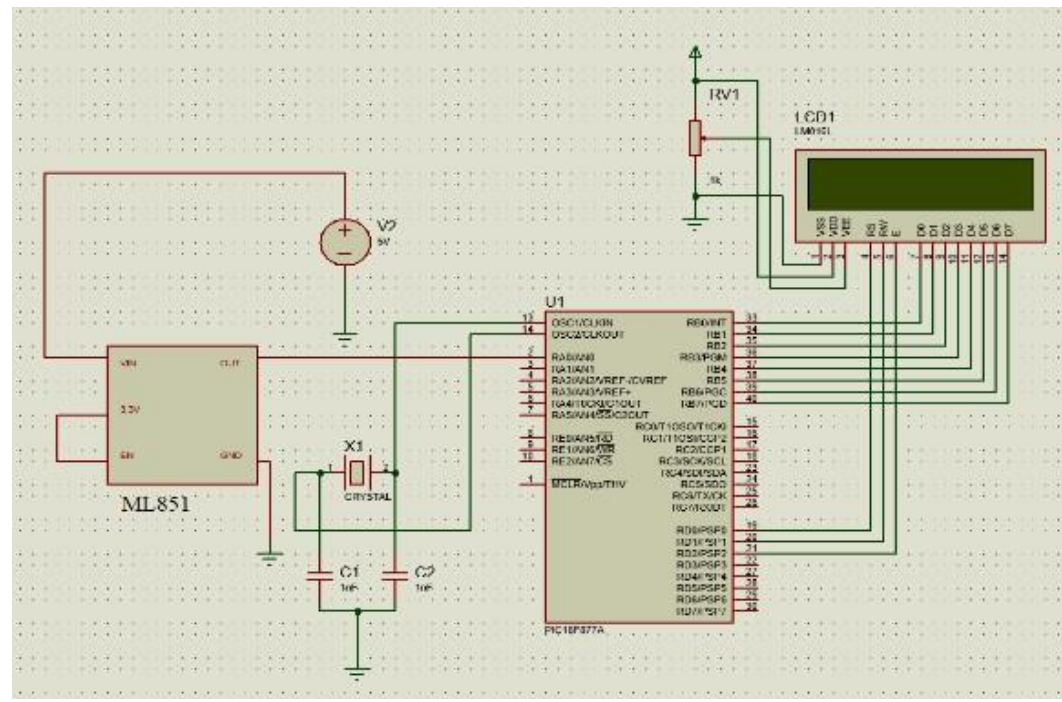

Gambar 3.8. Rangkaian Sensor ML8511

Dari Gambar 3.8. didapatkan 2 kali percobaan yaitu pengukuran pada matahari langsung dan pengukuran pada lampu UV. Untuk perbandingan nilai sensor ML8511 dengan UV meter dapat dilihat pada Tabel 3.8. dan Tabel 3.9.

Tabel 3.8. Hasil Perbandingan UV meter dan Sensor ML8511 pada Matahari

\begin{tabular}{|c|c|c|c|c|c|}
\hline Percobaan & $\begin{array}{c}\text { UV } \\
\text { Meter }\end{array}$ & $\begin{array}{l}\text { Sensor } \\
\text { ML8511 }\end{array}$ & Selisih & Status & Satuan \\
\hline 1 & 1,52 & 1,74 & $-0,22$ & Pukul 9 & \multirow{12}{*}{$\mathrm{mW} / \mathrm{cm}^{2}$} \\
\hline 2 & 3,42 & 3,54 & $-0,12$ & Pukul 10 & \\
\hline 3 & 3,9 & 3,89 & 0,01 & $\begin{array}{c}\text { Pukul } 10 \text { lebih } 20 \\
\text { Menit }\end{array}$ & \\
\hline 4 & 4,69 & 4,67 & 0,02 & Pukul 11 & \\
\hline 5 & 5,6 & 5,85 & $-0,25$ & Pukul 12 & \\
\hline 6 & 4,35 & 4,29 & 0,06 & Pukul 13 & \\
\hline 7 & 4,11 & 3,96 & 0,15 & $\begin{array}{c}\text { Pukul } 13 \text { lebih } 15 \\
\text { Menit }\end{array}$ & \\
\hline 8 & 2,44 & 2,13 & 0,31 & Pukul 14 & \\
\hline 9 & 2,16 & 1,95 & 0,21 & $\begin{array}{l}\text { Pukul } 14 \text { lebih } 15 \\
\text { menit }\end{array}$ & \\
\hline 10 & 0,84 & 1,12 & $-0,28$ & Pukul 15 & \\
\hline 11 & 0,27 & 0,43 & $-0,16$ & Pukul 16 & \\
\hline 12 & 0,24 & 0,13 & 0,11 & Kondisi Mendung & \\
\hline
\end{tabular}

Tabel 3.9. Hasil Perbandingan UV meter dan Sensor ML8511 pada Lampu UV 


\begin{tabular}{|c|c|c|c|c|c|}
\hline Percobaan & $\begin{array}{c}\text { UV } \\
\text { Meter }\end{array}$ & $\begin{array}{l}\text { Sensor } \\
\text { ML8511 }\end{array}$ & Selisih & Status & Satuan \\
\hline 1 & 7,13 & 2,57 & 4,56 & Lampu jarak $10 \mathrm{~cm}$ & \multirow{8}{*}{$\mathrm{mW} / \mathrm{cm} 2$} \\
\hline 2 & 1,35 & 0,89 & 0,46 & Lampu jarak $20 \mathrm{~cm}$ & \\
\hline 3 & 0,54 & 0,58 & $-0,04$ & Lampu jarak $30 \mathrm{~cm}$ & \\
\hline 4 & 0,31 & 0,38 & $-0,07$ & Lampu jarak $40 \mathrm{~cm}$ & \\
\hline 5 & 0,21 & 0,22 & $-0,01$ & Lampu jarak $50 \mathrm{~cm}$ & \\
\hline 6 & 0,18 & 0,13 & 0,05 & Lampu jarak $60 \mathrm{~cm}$ & \\
\hline 7 & 0,12 & null & null & Lampu jarak $70 \mathrm{~cm}$ & \\
\hline 8 & 0,1 & null & null & Lampu jarak $80 \mathrm{~cm}$ & \\
\hline
\end{tabular}

Dari data tabel 3.8 dan tabel 3.9. didapatkan nilai rata - rata selisih sensor keseluruhan sebesar 0,266. Dari hasil rata - rata sensor ini dimasukkan kedalam program untuk ditambahkan kedalam rumus perhitungan sensor untuk mendapatkan nilai UV. Dan hasil pengukuran berikutnya ini sensor sudah ditambah nilai rata - rata errornya. Pengukuran berikutnya dilakukan pengukuran pada 6 buah lampu UV yang intensitasnya sudah berubah setiap jamnya sesuai tabel 3.9. dan didapatkan hasil pengukuran pada tabel 3.10.

Tabel 3.10. Hasil Perbandingan UV Meter dengan Sensor ML8511

pada Lampu UV yang Sudah Diperbaiki

\begin{tabular}{cccccc}
\hline NO & $\begin{array}{c}\text { Sensor } \\
\text { ML8511 }\end{array}$ & UV Meter & Selisih & Status & $\begin{array}{c}\text { PWM } \\
(\%)\end{array}$ \\
\hline 1 & 0,172 & 0,118 & 0,054 & Pukul 07:00 & 25 \\
\hline 2 & 0,324 & 0,298 & 0,026 & Pukul 08:00 & 35 \\
\hline 3 & 0,437 & 0,818 & $-0,381$ & Pukul 09:00 & 50 \\
\hline 4 & 0,948 & 2,063 & $-1,115$ & Pukul 10:00 & 78 \\
\hline 5 & 1,089 & 2,886 & $-1,797$ & Pukul 11:00 & 83 \\
\hline 6 & 1,382 & 3,242 & $-1,86$ & Pukul 12:00 & 88 \\
\hline 7 & 1,089 & 2,414 & $-1,325$ & Pukul 13:00 & 80 \\
\hline 8 & 0,437 & 1,154 & $-0,717$ & Pukul 14:00 & 53 \\
\hline 9 & 0,321 & 0,311 & 0,01 & Pukul 15:00 & 31 \\
\hline 10 & 0,138 & 0,119 & 0,019 & Pukul 16:00 & 25 \\
\hline
\end{tabular}

Dari hasil tabel 3.10. dapat dikatakan selisih yang didapatkan ada yang besar dan ada juga selisih yang kecil bahkan mendekati sama, hal ini dikarenakan pada UV meter sensor sudah didesain sedemikian mungkin untuk menangkap cahaya agar masuk tepat ke sensor, sedangkan pada sensor 
menggunakan mikro ini tidak menggunakan desain apa - apa untuk menangkap cahaya ke sensor. Untuk pengambilan data sensor pada matahari ini sensor dapat dikatakan akurat walaupun masih memiliki selisih. Dapat dilihat pada percobaan 1 sampai 12 pada tabel 4.8. Saat pengambilan data pada matahari ini sensor tidak menggunakan alat bantu apa - apa. Sedangkan pada pengambilan data pada lampu pada percobaan 1 sampai 8 pada table 3.9. ini awalnya sensor tidak dapat membaca nilai dari radiasi keluaran dari lampu tersebut, sensor dapat membaca bila jarak lampu dan sensor kurang lebih sekitar $0,5 \mathrm{~cm}$.

Pada percobaan ini dilakukan pendesainan sensor dengan menggunakan lensa cembung yang ada pada laser untuk presentasi atau mainan anak - anak, lensa ini diarahkan ke sensor ML8511, dan saat dicoba kembali sensor dapat membaca nilai radiasi lampu tetapi hanya sampai jarak $60 \mathrm{~cm}$ saja, selebihnya sensor tidak dapat membaca. Seperti halnya pada percobaan 1 pada tabel 4.13, UV meter mendapatkan radiasi 7.13 sedangkan sensor ML8511 ini mendapakan radiasi hanya sebesar 2,57, dan juga pada tabel 3.10. nilai sensor sudah dikoreksi dengan penambahan nilai error yang diharapkan dapat sesuai dengan UV meter tetapi sensor masih kurang sensitive untuk membaca nilai radiasi dari lampu. hal ini mungkin dikarenakan desain yang dibuat kurang bagus atau kurang akurat agar cahaya dapat focus ke dalam sensor langsung. menggunakan desain lensa cembung ini juga harus diperkirakan karena cahaya focus yang masuk kesensor ini bila terlalu focus itu dapat merusak sensor karena panas. Karena sensor ini memiliki Batasan suhu sebesar $60-70^{\circ} \mathrm{C}$

\section{KESIMPULAN}

Dari percobaan yang telah dilakukan dapat disimpulkan bahwa:

1. Nilai radiasi berbanding lurus dengan nilai tegangan pada lampu. semakin kecil tegangan yang diberikan semakin kecil pula nilai radiasi yang didapat. Hal ini membuktikan bahwa nilai PWM sebanding dengan nilai intensitas sinar UV.

2. RTC (Real Time Clock) dapat difungsikan sebagai timmer untuk mengatur nilai PWM lampu pada setiap jamnya, dengan mengaturnya nilai PWM maka radiasi pada lampu UV akan ikut berubah.

3. Perbandingan sensor ML8511 dengan UV meter mendapatkan hasil yang kurang baik karena masih memiliki nilai error yang besar, hal ini dikarenakan pada UV meter sudah didesain sedemikian mungkin agar cahaya focus pada sensor, sedangkan pada sensor ML8511 tidak didesain untuk hal itu.

4. 4. Menggunakan sensor ML8511 ini lebih baik digunakan untuk pengukuran pada outdoor atau pada matahari bukan untuk lampu.

5. Driver AC menggunakan mosfet IRFP460 ini dapat di aluri beban hingga 1000W. tetapi alangkah baiknya menggunakan beban yang kurang dari 1000W agar mosfet bekerja dengan maksimal.

6. Driver AC menggunakan mosfet IRFP460 ini bila ditambahkan beban maka tegangan ouput beban akan turun. Hal ini mungkin dikarenakan arus atau tegangan yang digunakan itu bukan AC murni, karena menggunakan diode bridge untuk menyearahkan tegangan. Bila diukur menggunakan multimeter maka bisa mendapakan nilai tegangan DC maupun AC. Nilai tegangan AC ini akan 2 kali lipat nilai teganan DC tersebut. 


\section{DAFTAR PUSTAKA}

[1] Administrator. 2010. DS130764X8 Serial Real Time Clock. (online) (http//www.maxim-ic.com diakses tanggal 3 Maret 2018 pukul 21.05).

[2] Administrator. 2014. Pengertian Optocoupler dan Prinsip Kerjanya. (online) https://teknikelektronika.com/penger tian-optocoupler-fungsi-prinsip- kerja-ptocoupler/ diakses tanggal 2 Maret 2018 pukul 19.32).

[3] Agustin Rissa. 2013. Pengontrolan Kecepatan Motor DC Pada Penyimpanan Tempe Menggunakan Sinar Ultra Violet Berbasis Kontrol Logika Fuzzy. Malang: Universitas Brawijaya.

[4] Dwiono, W. 2014. Pemrograman PIC 16F877A Menggunakan MikroC PIC. Yogyakarta: Graha Ilmu.

[5] Firdaus Zahrotul, Ratnawati, Sugiyarto Lili. Pengatuh Polinasi Dengan Polen Yang Diiradiasi Sinar Ultraviolet Terhadap Pertumbuhan Tongkol Dan Produksi Buah Jagung (Zea mays L.) Kultivar Lokal Madura. Yogyakarta: Universitas Negeri Yogyakarta.

[6] Hendriyanto Okik. Pengaruh Intensitas Sinar Ultraviolet Dan Pengadukan Terhadap Reduksi Jumlah Bakteri E-coli. Jurnal Ilmiah Teknik Lingkungan Vol.2 No. 1, Hal 18-23.

[7] Hollaender. 1995. Effects Of Radiation On Bacteria. Radiation Biology, Vol. II, Cornell University, Itacha N.Y.

[8] Restiani Reni, Triyono Sugeng, Tusi Ahmad, Zahab Ridwan, Ag. 2015. Pengaruh Jenis Lampu Terhadap Pertumbuhan Dan Hasil Produksi Tanaman Selada (Lactuca sativa L.) Dalam Sistem Hidropinik Indoor. Jurnal Teknik Pertanian Lampung, Vol. 4, No. 3, Hal 219-226.

[9] Sitepu Jimmi, 2018. Pengertian MOSFET, Cara Kerja dan Manfaat nya. (Online) (https://mikroavr.com/pengertianmosfet-dan-manfaat-nya/ diakses tanggal 20 Juli 2018 pukul 09.13).

[10] Turesna Ganjar, Zulkarnain, Hermawan. 2015. Pengendali Intensitas Lampu Ruangan Berbasis Arduino UNO Menggunakan Metode Fuzzy Logic. J.Oto.Ktrl.Inst (J.Auto.Ctrl.Ins) Vol 7 (2), ISSN : 2085-2517. 